Wojciech Kowalski

wojciech.kowalski@us.edu.pl

orcid.org/0000-0001-6532-9796

Uniwersytet Śląski

Wydział Prawa i Administracji

ul. Bankowa 11b

40-007 Katowice

\title{
Miasta i ich symbole. \\ Uwarunkowania prawne \\ marketingowego wykorzystywania \\ wyglądu znanych zabytków
}

Cities and their symbols.

Legal conditions for marketing use

of the appearance of famous monuments

Summary: The subject of this article is the legal ramifications of the commercial use of well-known landmarks by the cities where they are located. In fact, cities have played such a role and benefited commercially for many years, e.g. the Eiffel Tower in Paris or Tower Castle in London. Such a practice appears obvious but should be based on the local legal provisions in force and resulting limitations. After a detailed analysis of the law of property and copyright, the author argues that the owner of the landmark has not only an exclusive right to make physical use of it, but also the right to dispose of its image. In particular, these rights include the commercial use of this image in both possible forms, whether looking at the monument directly or enjoying it by looking at its photographs. Taking into account this legal position, a city can freely use its marketing images of its own landmarks, but in the case of third party owned monument, it will be necessary to sign a special agreement setting out the conditions of such use. Independently of property rights, a city will be obliged to also accept the rights of authors of projects referred to as "new monuments" as well as the rights of the authors of projects 


\section{ARTYKUEY}

Wojciech Kowalski

involving conservation, restauration, adaptation and modernization works. These rights include economic rights and authorship of the given works (moral rights). In case of reconstructions and copies, such obligations refer only to the executors of the works.

Keywords: cities, marketing, monuments, ownership, copyrights

Streszczenie: Tematem artykułu są ramy prawne marketingowego wykorzystania znanych zabytków, szczególnie przez miasta, w których się one znajdują. Rolę taką odgrywają już od dawna np. wieża Eiffla w Paryżu czy zamek Tower w Londynie. Praktyka owa jest dość oczywista, ale musi jednak uwzględniać miejscowe uwarunkowania prawne i wynikające z nich ograniczenia. Po analizie prawa własności oraz prawa autorskiego autor dowodzi, że właściciel ma wyłączne prawo korzystania, a w tym również dysponowania wyglądem budowli zabytkowych. W szczególności obejmuje ono korzystanie z tego wyglądu w celach komercyjnych, czy to poprzez bezpośrednie oglądanie, czy też za pośrednictwem fotografii i innych nośników służących do utrwalania owego wyglądu. Jeżeli zatem w marketingu miasta ma być wykorzystany wygląd zabytków stanowiących własność danej gminy miejskiej, to wykonując to prawo, może ona w pełni korzystać z ich wyglądu w swoim marketingu. Gdyby zaś były one własnością innego podmiotu, to niezbędne będzie zawarcie z nim odpowiedniej umowy. Korzystając natomiast z wyglądu nowej budowli wpisanej do rejestru lub zabytku, który uwidacznia wyniki wykonanych prac konserwatorskich, restauratorskich lub adaptacyjnych i modernizacyjnych, miasto będzie musiało zarówno uwzględnić prawa autorskie twórców projektów tych prac, w tym prawa majątkowe związane z rozpowszechnianiem ich utworów, jak i ujawnić ich autorstwo w sposób z nimi ustalony. Gdyby zabytek był zaś rekonstrukcją lub kopią, to wówczas obowiązek ten dotyczy tylko autorstwa ich wykonawcy.

Słowa kluczowe: miasta, marketing, zabytki, prawo własności, prawa autorskie

\section{Wprowadzenie}

Analizę uwarunkowań prawnych wykorzystania znanych zabytków w marketingu miast należy rozpocząć od generalnej uwagi wstępnej, która otwierała już wcześniejszy tekst autora poświęcony tematyce wykorzystania marketingowego nazw 
Miasta i ich symbole. Uwarunkowania prawne marketingowego wykorzystywania...

Cities and their symbols. Legal conditions for marketing use...

i herbów przez inteligentne miasta (smart cities) ${ }^{1}$. W obydwóch przypadkach chodzi o wykorzystanie elementów szeroko pojętej własności intelektualnej miast, do której należą zarówno omówione już tam nazwy i herby, jak i poddany analizie w tym miejscu wygląd symbolizujących te miasta zabytkowych budowli. Wspólnym celem strategicznym tych zabiegów jest przede wszystkim definiujący je proces ponadprzeciętnego, inteligentnego wzrostu (smart growth), generujący w omawianych wypadkach dodatkowe wpływy finansowe ${ }^{2}$.

Aby zilustrować zjawisko będące przedmiotem rozważań w niniejszym artykule, wystarczy wymienić najbardziej znane przykłady, a mianowicie paryską wieżę Eiffla, nowojorską Statuę Wolności czy londyńskie Tower i wieżę z zegarem Big Ben. Nie wymaga przecież specjalnego dowodu twierdzenie, że każdy ze wspomnianych obiektów symbolizuje swoje miasto w szerokim odbiorze społecznym, i to w skali międzynarodowej. Co warto zaznaczyć, funkcja ta nie jest zwykle zależna od jakiegoś szczególnego znaczenia danej budowli jako takiej ani też jakiejś jej wyjątkowej historycznej roli. Obok wieży Eiffla znajduje się przecież w Paryżu wiele znakomitszych zabytków, podobnie jak Nowy Jork słynie nie tylko z tej statuy, a Londyn ze wskazanych budowli, chociaż wszystkie one są oczywiście bardzo ważne. Istotą ich wtórnej, marketingowej funkcji jest uzyskana przez nie niezwykła popularność, wciąż rozszerzana i wzmacniana umieszczaniem ich wyglądu na niezliczonych materiałach promocyjnych i wyrobach pamiątkarskich.

Tkwiący w takich obiektach potencjał marketingowy został już także dostrzeżony przez władze samorządowe miast polskich i bywa eksploatowany, ale inaczej niż w przypadku nazw i herbów, wykorzystywanie budowli w tym celu jest z punktu widzenia prawa bardziej złożone. W grę wchodzą tu bowiem prawa ich właścicieli, a po ewentualnej konserwacji, restauracji, adaptacji lub modernizacji zabytku także prawa architektów, którzy opracowali projekty tych prac i są ich autorami w rozumieniu art. 1 ustawy o prawie autorskim i prawach pokrewnych ${ }^{3}$ (dalej: prawo autorskie). Dodatkową komplikacją jest nadto niejasność zakresu prawa własności w omawianym kontekście, który w wyniku braku niezbędnej praktyki nie przeszedł jeszcze „testu sądowego” i na razie może być interpretowany jedynie na płaszczyźnie doktrynalnej. Zarysowane zagadnienie powinno być jednak podjęte i wyjaśnione, gdyż - w przekonaniu autora - ma ono niewątpliwą przyszłość i należy bliżej przyjrzeć się tej kwestii. Zadanie to wydaje się być jednocześnie pilne, gdyż obserwujemy już w Polsce zjawisko korzystania z wyglądu zabytków przez miasta, które jednak nie dostrzegają chyba pełni tkwiącego w tym potencjału. Pojawia się

1 W. Kowalski, Inteligentne miasta, a ich własność intelektualna. Status prawny oraz ochrona i używanie nazw i herbów, w: I. Jonek-Kowalska, J. Kaźmierczak (red.), Inteligentny rozwój inteligentnych miast, CeDeWu, Warszawa 2020, s. 101-121.

2 G. Masik, D. Studzińska, Ewolucja koncepcji i badania miasta inteligentnego, „Przegląd Geograficzny” 2018, nr 90(4), s. 557-571.

3 Ustawa z dnia 4 lutego 1994 o prawie autorskim i prawach pokrewnych, Dz. U. Nr 24, poz. 83 ze zm. zm. 


\section{ARTYKUŁY}

Wojciech Kowalski

przy tym swoista konkurencja w postaci reklamowej eksploatacji tych obiektów przez różne inne podmioty, szczególnie gospodarcze, co w przypadku utrwalenia się takiej praktyki może utrudnić realizację i ochronę praw gmin miejskich.

Kończąc uwagi wprowadzające, wskazać można dla zilustrowania omawianej tematyki jedynie zabytki znane powszechnie, które już pełnią wspomnianą funkcję, takie jak warszawska Kolumna Zygmunta, Zamek Królewski, Żuraw gdański czy Barbakan w Krakowie. Ze względu na złożoność problematyki prawnej analizę zarysowanego tematu przeprowadzić należy odrębnie w odniesieniu do zabytków jako takich, a następnie budowli zabytkowych poddanych konserwacji i restauracji, adaptacji i modernizacji oraz rekonstrukcji. Całość tych rozważań zakończy ogólne podsumowanie i sformułowanie wniosków.

\section{Korzystanie z wyglądu zabytków}

Na wstępie należy podkreślić, że terminu „zabytek” użyto tutaj w znaczeniu bardzo ogólnym, odnoszącym się do wszystkich obiektów stanowiących zasób dziedzictwa kulturowego, które powstały w przeszłości. Celem takiego podejścia było podkreślenie, że chodzi o budowle, które co do zasady nie są objęte ochroną prawnoautorską, chociaż mogą się od tej zasady zdarzyć pewne wyjątki, np. kiedy zabytek jest rekonstrukcją lub poddany był zabiegom adaptacyjnym bądź konserwatorskim ${ }^{4}$. Zagadnienia te wyjaśnione będą dalej, a w tym miejscu wystarczy dodać, że dla omawianych kwestii nie ma znaczenia uznanie danego obiektu za zabytek w rozumieniu art. 3 ust. 1 ustawy o ochronie zabytków i opiece nad zabytkami ${ }^{5}$. Jeżeli zatem nawet w myśl zawartej w tym przepisie definicji będzie to nieruchomość lub rzecz ruchoma, będąca dziełem człowieka lub związana z jego działalnością i stanowiąca świadectwo minionej epoki bądź zdarzenia, której zachowanie leży w interesie społecznym ze względu na posiadaną wartość historyczną, artystyczną lub naukową, to zostanie wówczas ona wpisana do rejestru zabytków i podlegać będzie wynikającej stąd ochronie prawnej, ale fakt ten ani nie tamuje, ani nie ogranicza korzystania z jej wyglądu' ${ }^{6}$.

\footnotetext{
4 Zabytkiem może też oczywiście być obiekt nowszy, który będzie przedmiotem ochrony prawnoautorskiej, a jednocześnie będzie objęty równoległą ochroną poprzez wpis do rejestru zabytków. Zagadnienie to pozostanie jednak poza analizą w niniejszym artykule. Szerzej na ten temat: W. Kowalski, Wartość zabytku a wartość adaptacji i modernizacji w świetle prawa autorskiego oraz prawa dziedzictwa kulturowego. Wzmocnienie ochrony czy konkurencja tych wartości?, w: B. Szmygin (red.), Ochrona wartości w procesie adaptacji zabytków, Polski Komitet Narodowy ICOMOS, Muzeum Pałacu Króla Jana III w Wilanowie, Politechnika Lubelska, Warszawa 2015, s. 133 in.

5 Ustawa z dnia 23 lipca 2003 r. o ochronie o ochronie zabytków i opiece nad zabytkami, Dz. U. Nr 162, poz. 1568 , ze zm. zm.

6 W. Kowalski, Prawna problematyka konserwacji zabytków, w: B. Szmygin (red.), Wspótczesne problemy teorii konserwatorskiej w Polsce, Międzynarodowa Rada Ochrony Zabytków ICOMOS, Politechnika Lubelska, Warszawa-Lublin, 2008, s. 52 i n.
} 
Miasta i ich symbole. Uwarunkowania prawne marketingowego wykorzystywania...

Cities and their symbols. Legal conditions for marketing use...

Ograniczenia takie wynikają natomiast, zdaniem autora, z prawa własności tego rodzaju obiektów. Ponieważ ramy niniejszego artykułu nie dopuszczają szerszych wywodów na ten temat, a jednocześnie teza ta została uzasadniona przy innych okazjach7, można w tym miejscu ograniczyć się do podania istoty zagadnienia. Otóż punktem wyjścia są tu treść i zakres wspomnianego prawa własności, wyznaczony przez art. 140 Kodeksu cywilnego ${ }^{8}$ (dalej: k.c.). Zgodnie z jego brzmieniem, „w granicach określonych przez ustawy i zasady współżycia społecznego właściciel może, z wyłączeniem innych osób, korzystać z rzeczy zgodnie ze społeczno-gospodarczym przeznaczeniem swego prawa, w szczególności może pobierać pożytki i inne dochody z rzeczy. W tych samych granicach może rozporządzać rzeczą". Pomijając ostatnie prawo właściciela (ius disponendi) jako nieistotne z punktu widzenia omawianej problematyki, należy w świetle tego przepisu podkreślić, że kontynuując tradycję rzymską ${ }^{9}$, ustawodawca wskazał trzy podstawowe uprawnienia właściciela rzeczy: prawo posiadania (ius possidendi), używania (ius utendi) oraz prawo do pobierania z nich pożytków i innych przychodów (ius abutendi). Najważniejsze dla dalszego toku rozważań jest trzecie z nich, polegające na możliwości pobierana pożytków i innych przychodów z rzeczy, w tym także stanowiących nieruchomości. Prawo to w sposób logiczny obejmuje nie tylko możliwość korzystania z materialnego ich komponentu, np. wynajmu powierzchni użytkowej budynku, ale także prawo korzystania z jego wyglądu i udostępniania go innym osobom. To ostatnie prawo dotyczy przy tym nie tylko możliwości oglądania budynku w sensie fizycznym, np. podziwiania zabytku in situ, ale również dysponowania jego wyglądem, który utrwalony został na fotografii lub innym nośniku. Nie da się bowiem uzasadnić odmiennego ewentualnie traktowania korzystania z wyglądu tego zabytku poprzez jego bezpośrednie oglądanie i korzystania z tego samego wyglądu, tyle że „oderwanego" od obiektu wskutek utrwalenia na jakimś nośniku. W każdym z tych przypadków chodzi przecież o ten sam wygląd tego samego zabytku, a różnica dotyczy jedynie sposobu oglądania - patrzenia bezpośrednio na obiekt lub za pośrednictwem jego utrwalenia. W konsekwencji brak jest przeszkód, aby do pożytków z rzeczy w rozumieniu powołanego wyżej art. 140 k.c. zaliczyć nie tylko dochody z bezpośredniego korzystania z jej wyglądu, ale także dochody wynikające z korzystania z tego wyglądu również w sytuacji zarejestrowania go na filmie, fotografii itp. Omówione prawo jest oczywiście czymś innym niż prawa autora tej fotografii

\footnotetext{
7 W. Kowalski, K. Zalasińska, Prawo do wyglądu muzealiów i ich fotografowania, „Państwo i Prawo” 2013, z. 2, s. 81-83; W. Kowalski, Pojęcie i zakres własności intelektualnej muzeów, w: P. Stec, P.P. Maniurka (red.), Kolekcje muzealne i zbiory. Problematyka prawna, Redakcja Wydawnictw Wydziału Teologicznego Uniwersytetu Opolskiego, Opole 2015, s. 175-177.

8 Ustawa z dnia 23 kwietnia 1964 r. Kodeks cywilny, tekst jedn. Dz. U. z 2020 r., poz. 1740, 2320, z 2021 r., poz. 1590.

9 J. Ignatowicz, K. Stefaniak, Prawo rzeczowe, wyd. 3, LexisNexis, Warszawa 2009, s. 65.
} 


\section{ARTYKUŁY}

Wojciech Kowalski

bądź filmu, które jako utwory w rozumieniu prawa autorskiego podlegają reżimowi tego prawa, a nie wyjaśnionej regulacji prawa rzeczowego.

Zaprezentowana teza nie jest odosobniona w polskiej doktrynie prawnej. W odniesieniu do zabytków była ona poddana szczegółowej analizie przez Monikę Drelę ${ }^{10}$, która uwzględniając opinie wyrażone w doktrynie obcej, zauważyła, że korzystanie z wyglądu rzeczy odbiega swym pojęciowym zakresem od pojęcia korzystania z samej rzeczy, ale gotowa jest uznać, że pierwsze wchodzi w obręb drugiego. Jak dalej wyjaśnia: „Możemy przecież z całą pewnością stwierdzić, że jeżeli właściciel czerpie korzyści z wyglądu rzeczy (np. udostępnia zwiedzającym za opłatą wnętrza pałacu czy obraz itp.), owa korzyść jest dochodem (pożytkiem cywilnym), który rzecz przynosi" ${ }^{\prime 1}$. We wnioskach swojej analizy cytowana autorka opowiedziała się „za zaliczeniem do treści prawa własności uprawnienia do decydowania o wyglądzie rzeczy oraz prawa do ukrycia rzeczy przed wzrokiem innych"12, a wywody swe na ten temat skonkludowała tezą, „że uprawnienie do czerpania korzyści ekonomicznych z wyglądu rzeczy jest objęte treścią prawa własności z wyłączeniem w tym zakresie majątkowych praw autorskich"13.

Tezę tę akceptują także inni polscy autorzy ${ }^{14}$, przy czym Elżbieta Traple w kontekście omawiania prawnoautorskiego reżimu utworów wystawionych na stałe w miejscach ogólnie dostępnych (art. 33 ust. 1 prawa autorskiego) także zwraca uwagę na prawo np. muzeum do udzielania zgody na sporządzanie i rozpowszechnianie reprodukcji eksponatów, które to uprawnienie oparte jest na prawie własności. „Najczęściej fotografowanie, szczególnie sprzętem profesjonalnym, zależy od zgody właściciela i zapłaty odpowiedniego wynagrodzenia"15. Kwestia ta wymaga dodatkowego wyjaśnienia, gdyż dla utrzymania spójności wywodu nie wspomniano wyżej, że oparte na art. 140 k.c. prawo właściciela do korzystania $z$ wyglądu rzeczy obejmuje w przekonaniu piszącego te słowa przede wszystkim korzystanie komercyjne, gdyż już nawet z czysto praktycznego względu trudno wyobrazić sobie możliwość zakazywania patrzenia na zabytek widoczny z miejsc łatwo dostępnych, a czasem nawet ze znacznej odległości. Należy też dodać konsekwentnie, że dotyczy to także możliwości amatorskiego wykonywania fotografii pamiątkowych, niesłużącego osiąganiu korzyści majątkowych. Taki też wniosek można wyciągnąć z cytowanego podglądu E. Traple, skoro autorka ta podkreśla użycie „sprzętu profesjonalnego".

10 M. Drela, Własność zabytków, C.H. Beck, Warszawa 2006, s. 158-164.

11 Ibidem, s. 158.

12 Ibidem, s. 163.

13 Ibidem, s. 164.

14 A. Niewęgłowski, M. Poźniak-Niedzielska, A. Przyborowska-Klimczak, Ochrona niematerialnego dziedzictwa kulturowego, Wolters Kluwer, Warszawa 2015, s. 76-77.

15 E. Traple, Komentarz do art. 33, w: J. Barta, M. Czajkowska-Dąbrowska, Z. Ćwiąkalski, R. Markiewicz, E. Traple, Prawo autorskie i prawa pokrewne, Wolters Kluwer, Warszawa 2011, s. 283. 
Miasta i ich symbole. Uwarunkowania prawne marketingowego wykorzystywania...

Cities and their symbols. Legal conditions for marketing use...

Przed pokazaniem funkcjonowania omówionego prawa w praktyce trzeba jeszcze odnotować głos przeciwny w tej sprawie, który opiera się na zarzucie, że „rozciągnięcie ochrony prawa własności na dobra niematerialne może powodować dublowanie podstaw ochrony oraz uniemożliwiać skuteczne i pewne wykonywanie praw własności intelektualnej”, a nadto ochrona taka „byłaby całkowicie nieadekwatna do potrzeb i wykraczałaby daleko poza uzasadnione interesy uprawnionego, z zasadniczym uszczerbkiem dla interesu publicznego" ${ }^{16}$. Nie wchodząc w tym miejscu w polemikę z tym poglądem, można jedynie zauważyć, że niezależnie od ewentualnych wątpliwości doktrynalnych korzystanie z wyglądu rzeczy wynikające z prawa jej własności jest faktem i odbywa się na coraz szerszą skalę. Jak podkreślono, opiera się na prawie własności i nie prowadzi do tworzenia nowego prawa własności intelektualnej, chyba że pojęcie to rozumiane będzie w tym kontekście bardzo szeroko, w sposób wychodzący poza to prawo w ścisłym rozumieniu. Warto też zauważyć, że w przypadku tzw. nowych zabytków, czyli obiektów wpisanych do rejestru przed wygaśnięciem praw autorskich ich twórcy - architekta ${ }^{17}$, zachowa on prawo do komercyjnego korzystania z wyglądu równolegle do takiego prawa właściciela obiektu, które wynika z prawa własności. Ta równoległość działania praw nie jest przy tym czymś nowym ani specjalnym, ale występuje np. w sytuacji korzystania z obrazu olejnego przez jego właściciela niezależnie od praw malarza, jeśli pozostają jeszcze w mocy ${ }^{18}$.

Jak podkreślono w uwagach wstępnych, zakres prawa własności w omawianym kontekście nie był jeszcze szerzej badany przez polskie sądy, chociaż dla kompletności analizy nie można pominąć jednego orzeczenia, które w swej istocie dotyczyło jednak innej kwestii i zostanie wyjaśnione dalej. Co do sedna sprawy wypowiadały się natomiast sądy niemieckie i francuskie. Jednoznacznie za ochroną omawianego prawa właściciela opowiedział się Federalny Trybunał Sprawiedliwości w Karlsruhe w orzeczeniu Schloss Tegel już w 1976 r. ${ }^{19}$ Oceniając wykonanie fotografii zamku i rozpowszechnianie ich na pocztówkach bez zgody jego właściciela, zastosował § 1004 Kodeksu cywilnego niemieckiego o ochronie własności przed naruszeniami w sposób inny niż pozbawienie lub naruszenie posiadania. Sprawę wykorzystania fotografii obiektów z kolekcji rzeczy ruchomych bez zgody jej właściciela rozpatrywał z kolei sąd koloński, który uznał, że w takich

\footnotetext{
16 K. Wojciechowski, Ochrona obrazu rzeczy, „Przegląd Prawa Handlowego” 2005, nr 1, s. 50-51.

17 Szerzej na ten temat: W. Kowalski, Prawno-autorska ochrona architektury XX wieku, „Ochrona Dziedzictwa Kulturowego" 2017, vol. 3, s. 29-44.

18 Szerzej na ten temat, w tym również o możliwym konflikcie tych praw: W. Kowalski, A Comparative Law Analysis of the Retained Rights of Artists, „Vanderbilt Journal of Transnational Law” 2005, vol. 38, nr 4, s. 1155 in.

19 BGH, U.v. 20.09.1974, Az. IZR 99/73.
} 


\section{ARTYKUŁY}

Wojciech Kowalski

warunkach dozwolona jest tylko publikacja niekomercyjna; w konkretnym wypadku było to zamieszczenie tych fotografii w pracy naukowej ${ }^{20}$.

Podobnie jak w przypadku zamku Tegel, także odwoławczy sąd paryski oparł prawo właściciela do wyglądu kawiarni Café Gondrée na przepisach dotyczących własności ${ }^{21}$, a konkretnie na art. 544 Kodeksu cywilnego francuskiego, w którym własność zdefiniowana została podobnie jak w art. 140 polskiego Kodeksu cywilnego. Stanowisko takie wyjaśnił inny sąd dwa lata później w sprawie widoku zabudowy wyspy Roh Archon, stwierdzając: „właściciel rzeczy ma również pewne prawo używania jej wyglądu, ponieważ wygląd przedmiotu własności nie może być od niego oddzielony, a zatem skoro właściciel jest panem swej rzeczy, to konsekwentnie jest również panem jej wyglądu"22. Pogląd ten nie utrzymał się jednak w ostatniej instancji i sąd kasacyjny uznał, że ochrona omawianego prawa wchodziłaby w grę jedynie w przypadku wywołania „nienormalnych zakłóceń” w korzystaniu z nieruchomości ${ }^{23}$.

Wspomniane orzeczenia wywołały ożywioną dyskusję w doktrynie prawniczej obydwóch krajów, zarówno w kierunku krytycznym, jak i aprobującym. Pewne jej aspekty wyjaśniono także w literaturze polskiej ${ }^{24}$, ale szersza ich analiza znacznie przekraczałaby ramy niniejszego tekstu, poświęconego przecież pozycji prawa polskiego.

Pozostaje zatem ograniczyć się do wyjaśnienia zasygnalizowanego już jedynego krajowego orzeczenia zapadłego w związku z fotografowaniem zabytków zgromadzonych w muzeum, które prima facie może być odczytane jako negatywna ocena prawa właściciela do wyłącznego korzystania z wyglądu jego rzeczy. Przedmiotem oceny sądu był punkt regulaminu Muzeum Regionalnego im. Dzieci Wrzesińskich we Wrześni o następującym brzmieniu: „Zabrania się fotografowania i filmowania eksponatów oraz sal ekspozycyjnych bez uzyskania pozwolenia dyrektora Muzeum. Fotografowanie możliwe jest po uzyskaniu zgody i uiszczenia opłaty". Sąd Ochrony Konkurencji i Konsumentów w wyroku z dnia 5 marca 2010 r. uznał ten zapis za tzw. niedozwoloną klauzulę umowną ${ }^{25}$. Muzeum nie odwołało się od tego wyroku, co może sprawić wrażenie, że zawarte w regulaminie prawo muzeom nie przysługuje. Analiza okoliczności wydania wyroku wskazuje wszak jednoznacznie na błąd w takim rozumowaniu. Otóż wydając taki wyrok,

20 OLG Köln, U.v. 25.02.2003, 15 U 138/02.

21 Cour de Cassation, Chambre civile 1, du 10 mars 1999, 96-18.699, Bulletin 1999 I No 87, 58.

22 Trib. Civ. 1re, du 2 mai 2001, JCP 2000. II. 10553.

23 Cour de Cassation, Assemblée plènière, du 7 mai 2004, 02-10.450 Bulletin 2004 A. P. No 10, 21.

24 K. Wojciechowski, op. cit., s. 47-49, M. Drela, op. cit., s. 155-157, W. Kowalski, K. Zalasińska, op. cit., s. 81-83, W. Kowalski, Pojęcie..., s. 175-177.

25 Wyrok Sądu Ochrony Konkurencji i Konsumentów z dnia 5 marca 2010 r., sygn.. akt XVII Amc 1145/09, „Monitor Sądowy i Gospodarczy” 2010, 147, 9641. 
Miasta i ich symbole. Uwarunkowania prawne marketingowego wykorzystywania...

Cities and their symbols. Legal conditions for marketing use...

sąd potraktował relację muzeum - zwiedzający jako paralelną do stosunku przedsiębiorca - konsument i wyciągnął z tego wniosek, że jest ona oparta na wzorcu umownym. Tymczasem natura tego związku ma charakter szczególnego stosunku administracyjnoprawnego, którego treść wyznacza regulamin korzystania wydany na podstawie władztwa zakładowego, a zatem zawarte w nim ograniczenia nie mogą być kwalifikowane jako elementy wzorca umownego. Taka ocena wyklucza zaś w ogóle możliwość zastosowania w opisanej sytuacji przepisów o niedozwolonych klauzulach umownych, a analizowany wyrok nakazuje uznać za nietrafny, co oznacza, że każde muzeum może w regulaminie określić sposób i zakres korzystania z wyglądu zbiorów wystawionych w nim do oglądania, w tym wolno mu także wprowadzić zakaz fotografowania ${ }^{26}$. Należy dodać, że - jak już wspomniano stanowisko to zostało generalnie zaaprobowane w doktrynie ${ }^{27}$.

Mając na względzie ten wniosek i wcześniej podniesione argumenty, można uznać, że w myśl prawa polskiego właściciel jest wyłącznym dysponentem wyglądu budowli zabytkowych, przynajmniej w zakresie wykorzystania tego wyglądu w celach komercyjnych. Podsumowanie to ma jednak charakter wstępny, gdyż sytuacja prawna zmienia się w przypadku obiektów poddanych zabiegom konserwatorskim i restauratorskim lub adaptacyjnym i modernizacyjnym, a także gdy są one rekonstrukcjami. Zacznijmy od dwóch pierwszych rodzajów wymienionych prac.

\section{Zabytek poddany zabiegom konserwatorskim i restauratorskim oraz adaptacji lub modernizacji}

Mimo pewnych wahań jeszcze 30 lat temu, dzisiaj nie budzi już wątpliwości to, że prace konserwatorskie i restauratorskie stanowią w swej kreatorskiej części przedmiot prawa autorskiego. Autor miał już okazję obszernie uzasadnić ten pogląd w innym miejscu ${ }^{28}$, natomiast tutaj, dla zachowania ciągłości wywodu, zdecydował przytoczyć swoje podstawowe ustalenia. Omówienie tej kwestii jest konieczne, albowiem w konsekwencji przeprowadzenia chronionych prawem autorskim prac konserwatorskich lub restauratorskich, obok omówionych wyżej praw właściciela, pojawić się mogą jeszcze prawa konserwatora, a w szczególności prawa konserwatora-autora ich projektu.

Zacząć trzeba od wyjaśnienia, dlaczego prace te są wspomnianym prawem chronione, skoro dotyczą zabiegów przeprowadzanych na istniejącym od dawna obiekcie, który sam w sobie zwykle nigdy nie był tym prawem chroniony, a nadto jaki związek mogą te prace mieć z jego wyglądem. Otóż decydujący jest twórczy

\footnotetext{
26 W. Kowalski, K. Zalasińska, op. cit., s. 78.

27 A. Niewęgłowski, M. Poźniak-Niedzielska, A. Przyborowska-Klimczak, op. cit., s. 76.

28 W. Kowalski, Prawno-autorska ochrona..., s. 29 i n.
} 


\section{ARTYKUŁY}

Wojciech Kowalski

charakter prac konserwatorskich i restauratorskich, który wynika z ustalenia, że praktycznie zawsze mają one nie tylko ściśle techniczny charakter ${ }^{29}$, ale zwykle w różny sposób ingerują w poddany im zabytek, wpływając na jego estetykę i wygląd $\mathrm{d}^{30}$. Na poziomie minimum jest to podjęta przez konserwatora przynajmniej „pewna liczba twórczych wyborów”31, a w ogromnej większości przypadków jest on „twórcą nowych jakości estetycznych w konserwowanym dziele, odsłaniając, dodając lub odejmując elementy"32. Taka konkluzja pozwala uznać, że praca ta spełnia kryteria utworu, którym musi być „przejaw działalności twórczej o indywidualnym charakterze, ustalony w jakiejkolwiek postaci, niezależnie od wartości, przeznaczenia i sposobu wyrażenia ", jak wymaga tego art. 1 prawa autorskiego. W konsekwencji zaś daje podstawę do uznawania pracy konserwatora za działalność chronioną tym prawem. Wątek ten można dodatkowo uzupełnić potwierdzeniem takiego stanowiska przez sąd, który co prawda dopiero w ostatniej instancji, a mianowicie w trybie kasacyjnym, uznał jednak twórczy charakter analizowanych prac. W swym wyroku z dnia 5 grudnia 2013 r. Naczelny Sąd Administracyjny w Warszawie ${ }^{33}$ wyjaśnił jednocześnie, że „zwolnienie [prac konserwatorskich jako utworu - dop. W.K.] od podatku od towarów i usług, przewidziane w art. 43 ust. 1 pkt 33b ustawy o VAT, nie będzie miało zastosowania do wszystkich usług świadczonych przez stronę. Dotyczy bowiem jedynie działań o charakterze twórczym, noszącym cechy indywidualne [...]. Natomiast powyższym zwolnieniem nie będą objęte działania o charakterze czysto technicznym. [...] Trzeba bowiem podkreślić, że prace konserwatorskie i restauratorskie maja bardzo szeroki zakres przedmiotowy". Niniejszy fragment uzasadnienia wyroku został przytoczony po to, aby podkreślić konieczność oddzielenia w zabytku wyglądu części starej, autentycznej, od wyglądu części wprowadzonej przez konserwatora. Jeżeli część nowa jest wyraźnie widoczna, to mamy wówczas do czynienia z równoległym wystąpieniem autorskich praw konserwatora obok praw właściciela, co komplikuje ewentualne wykorzystanie wyglądu zabytku w marketingu miasta. Trzeba bowiem wówczas uzyskać na to zgodę obydwóch tych osób, aczkolwiek z zupełnie innych powodów

29 C. Forder, Who's Afraid of Red, Yellow and Blue III?, „International Journal of Cultural Property” 1994, vol. 3 , nr 2, s. 90.

30 W. Kowalski, Ograniczenia prawne zmiany estetyki zabytku w trakcie jego konserwacji i restauracji, w: E. Szmit-Naud, B.J. Rouba, J. Arszyńska (red.), Wokół zagadnień estetyki zabytku po konserwacji i restauracji, Narodowy Instytut Dziedzictwa, Warszawa-Toruń 2012, s. 85 i n.

31 T. Dreier, Restoration as a work protected by copyright?, w: Q. Byrne-Sutton, M.M. Renold, B. Rötheli-Mariotti (red.), La restauration des objets d'art. Aspects juridiques et étiques. The Restoration of Works of Art. Legal and Ethical Aspects, Etudes en droit de l'art, vol. 6, Schulthess, Zürich 1995, s. 164.

32 G. Korpal, Artystyczny aspekt procesu konserwacji, w: B. Szmygin (red.), Współczesne problemy teorii konserwacji w Polsce, s. 45; eadem, Wokół kreacji, w: E. Szmit-Naud, B.J. Rouba, J. Arszyńska (red.), Wokół zagadnień..., s. 43 in.

33 Wyrok Naczelnego Sądu Administracyjnego w Warszawie z dnia 5 grudnia 2013 r., sygn: I FSK 1750/12, niepubl. 
Miasta i ich symbole. Uwarunkowania prawne marketingowego wykorzystywania...

Cities and their symbols. Legal conditions for marketing use...

jurydycznych. W odniesieniu do konserwatora uwzględnić trzeba będzie przy tym nie tylko kwestie jego praw majątkowych związanych z rozpowszechnianiem jego „konserwatorskiego” utworu, ale także autorskich praw osobistych. Zgodnie z art. 16 prawa autorskiego, przysługują mu bowiem m.in. prawo do autorstwa utworu oraz prawo do oznaczania utworu swoim nazwiskiem lub pseudonimem albo do udostępniania go anonimowo.

Z podobną sytuacją będziemy mieli do czynienia w przypadku wykonania przy zabytku prac adaptacyjnych i modernizacyjnych ${ }^{34}$. Należy nawet założyć, że z natury swej prace te będą bardziej „inwazyjne” i wywrą większe piętno na jego wyglądzie, szczególnie gdy w ich wyniku ulega zmianie funkcja obiektu. W konsekwencji przeto „udział” projektanta takich prac w owym wyglądzie będzie zwykle większy niż przy konserwacji bądź restauracji, które polegają zasadniczo na zachowaniu i zabezpieczeniu stanu istniejącego. Adaptacja i modernizacja mają zatem zwykle znacznie szerszy zakres i zaczynają się od opracowania przez architekta odpowiedniej koncepcji, która następnie znajdzie swoją konkretyzację w przygotowanej przez niego dokumentacji projektowej ${ }^{35}$. Jego swoboda jest oczywiście ograniczona przez wymogi konserwatorskie zawarte w przepisach o ochronie zabytków, ale mimo to pozostaje mu zwykle spora przestrzeń w kreowaniu tej koncepcji i sposób skorzystania z niej wynika z jego talentu i doświadczenia. Potwierdzają to znane przykłady, jak choćby przykrycie szklanym dachem Wielkiego Dziedzińca w Muzeum Brytyjskim w 2000 r. autorstwa architekta Normana Fostera, które jest uznawane za wzór modernizacji zabytku nie tylko nie naruszającej jego substancji zabytkowej, ale jednocześnie wzbogacającej jego walory artystyczne. Mając na względzie te argumenty, należy przyjąć, że adaptacja i modernizacja zabytków stanowią, podobnie jak omówiona wyżej konserwacja, utwór w rozumieniu prawa autorskiego i podlegają ochronie zarówno w zakresie autorskich praw majątkowych, jak i autorskich praw osobistych.

\section{Rekonstrukcje}

Zupełnie inaczej przedstawia się natomiast prawna ocena prac rekonstrukcyjnych, przy czym zagadnieniu trzeba poświęcić szczególną uwagę, gdyż z powodu niekorzystnych zaszłości historycznych sporo zabytków w Polsce jest rekonstrukcjami ${ }^{36}$. Dotyczy to także zabytków o znaczeniu symbolicznym, których wygląd już jest lub może być wykorzystany przez miasta do ich marketingu. Wystarczy wspomnieć

\footnotetext{
34 Szerzej: J. Barta, R. Markiewicz, Problemy prawa autorskiego związane z rewaloryzacją zabytkowych budowli, „Kwartalnik Prawa Prywatnego” 1993, t. 3, s. 265 i n.

35 W. Kowalski, Wartość zabytku..., s. 136.

36 W. Kowalski, Prawno-autorska ochrona..., s. 29 i n.
} 


\section{ARTYKUŁY}

Wojciech Kowalski

Zamek Królewski w Warszawie, który w czasie wojny został całkowicie zburzony, a zatem powojenna odbudowa oznaczała jego odtworzenie $w$ całości $^{37}$. Innym przykładem jest jeden z symboli Gdańska, drewniany Żuraw z pierwszej połowy XV w., odbudowany w 1956 r. po spaleniu pod koniec wojny ${ }^{38}$.

Przystępując do analizy statusu prawnego omawianych obiektów, należy na wstępie wyjaśnić, czym jest rekonstrukcja i w jaki ewentualnie sposób różni się od dzieła oryginalnego. Zgodnie z definicją encyklopedyczną, stanowi ona „odtworzenie, odbudowę, uzupełnienie brakujących fragmentów dzieła sztuki, zwłaszcza budowli, według zasad konserwacji" ${ }^{39}$. Ponieważ wykonanie opisanych czynności opiera się na posiadanych informacjach o odtwarzanym obiekcie, jego konstrukcji i wyglądzie, to co do zasady prace te nie mogą mieć charakteru twórczego. Nie zmienia tego faktu konieczność posiadania odpowiedniego talentu i umiejętności do wykonania rekonstrukcji, do odtworzenia nieistniejącego przecież budynku, rzeźby czy malowidła. Niezależnie od konieczności spełnienia tych niezbędnych wymogów, które niewątpliwie warunkują udane wykonanie zamierzenia, w kategoriach prawnych końcowy wynik pracy rekonstruktora polega jedynie na niewymagającym twórczości odtworzeniu czegoś, co już istniało. Można nawet powiedzieć, że otworzenie nieistniejącego obiektu w sposób odpowiadający w pełni pierwowzorowi jest jedynie powtórnym utrwaleniem tego samego dzieła, czyli utworu w rozumieniu cytowanego wyżej art. 1 prawa autorskiego. Ponieważ rekonstruktor nie jest autorem tego dzieła jako takiego, czyli inaczej projektu budowli pierwotnej jako dobra niematerialnego, a jedynie wykonawcą jego ponownego utrwalenia w rozumieniu technicznym, to utrwalenie to - jako pozbawione wymaganych w powołanym przepisie cech twórczości, oryginalności i indywidualności - nie będzie mogło podlegać ochronie prawa autorskiego ${ }^{40}$. Wyjaśnienie to w sposób naturalny odnosi się do rekonstrukcji w pełnym tego słowa znaczeniu, to znaczy odtworzenia wiernego dawnej postaci nieistniejącego utrwalenia utworu. Tylko taki wynik pracy rekonstruktora może być bowiem uznany za rekonstrukcję „zgodną z zasadami konserwacji”. Jeżeli jednak dopuszczona zostanie jakaś swoboda w opisanym procesie odtwarzania, zwykle będąca wynikiem braku pełnych informacji o pierwotnym obiekcie, to wówczas nie wchodzi już w grę klasyczna postać rekonstrukcji. Dodane przez rekonstruktora fragmenty mogą być wtedy wynikiem jego inwencji artystycznej $\mathrm{i}$ - podobnie jak

37 Por. m.in. J. Dąbrowski, Problem rekonstrukcji części gotyckiej zamku oraz przywrócenia zespołu wnętrz z czasów Władysława IV, „Ochrona Zabytków” 1949, nr 2-4, s. 227-236; J. Zachwatowicz, Zagadnienie odbudowy zamku jako rekonstrukcji jego formy i wnętrza. Zamek Warszawski. „Ochrona Zabytków” 1949, nr 2-4, s. 274-282.

38 E. Zbierska, Żuraw Gdański, Wydawnictwo Gdańskie, Gdańsk 1993.

39 Rekonstrukcja, hasło w: Mała encyklopedia PWN, PWN, Warszawa 1992.

40 W. Kowalski, Conservation of Works of Art under Polish Copyright Law, „Art, Antiquity and Law” 1999, vol. 4, nr 2, s. 119 in. 
Miasta i ich symbole. Uwarunkowania prawne marketingowego wykorzystywania...

Cities and their symbols. Legal conditions for marketing use...

w przypadku omówionych wyżej prac konserwatorskich, restauratorskich i adaptacyjnych - zostaną one zakwalifikowane jako wkład twórczy do odtwarzanego obiektu, który chroniony będzie prawem autorskim.

Na marginesie należy jeszcze zauważyć, że ocenę tę trzeba odnieść również do kopii, stanowiącej w myśl definicji słownikowej wierne odtworzenie wszystkich elementów kopiowanego dzieła ${ }^{41}$. Różnica w stosunku do rekonstrukcji polega bowiem jedynie na tym, że rekonstruktor odtwarza na podstawie zachowanych informacji nieistniejące w tym czasie utrwalenie powstałego wcześniej utworu, podczas gdy kopista, zmierzając do tego samego celu, wzoruje się na istniejącym utrwaleniu, pozostającym najczęściej w jego bezpośrednim zasięgu. Zarówno w pierwszym, jak i w drugim przypadku brak jest miejsca na ich inwencję twórczą, a zatem efektom ich pracy nie może być przyznana ochrona prawnoautorska. Trzeba jednocześnie wyjaśnić, że nie oznacza to jeszcze pozbawienia ich jakiejkolwiek ochrony prawnej. Wynika ona bowiem z art. 23 k.c., w myśl którego: „Dobra osobiste człowieka, jak w szczególności [...] nazwisko lub pseudonim, [...] twórczość naukowa, artystyczna, [...] pozostają pod ochroną prawa cywilnego niezależnie od ochrony przewidzianej w innych przepisach”. Ten zaś, „czyje dobro osobiste zostaje zagrożone cudzym działaniem, może żądać zaniechania tego działania, chyba że nie jest ono bezprawne. W razie dokonania naruszenia może on także żądać, ażeby osoba, która dopuściła się naruszenia, dopełniła czynności potrzebnych do usunięcia jego skutków, w szczególności złożyła oświadczenie odpowiedniej treści i w odpowiedniej formie" (art. 24 k.c.). Przepisy te przytoczono prawie w całości, gdyż są one podstawą ochrony autorstwa także w przypadku rekonstrukcji i kopii. Niezależnie przecież od wyjaśnionego braku elementu twórczości, wykonawcy rekonstrukcji i kopii pozostają ich „autorami” w węższym, potocznym sensie i ten fakt winien być zaznaczony, obok wskazania autora utworu pierwotnego, zarówno na dziele zrekonstruowanym, jak i na kopii. Konsekwentnie okoliczność ta nie może zostać pominięta przy ewentualnym wykorzystywaniu wyglądu takich obiektów w marketingu miasta.

\section{Podsumowanie i wnioski}

Rekapitulując analizy poczynione w niniejszym rozdziale, można w opinii autora wyciągnąć z nich wniosek, że podobnie jak nazwy i herby, również wygląd znajdujących się w miastach zabytków może stanowić istotny składnik ich ogólnie pojętej własności intelektualnej. Jako taki może on być w szczególności komercjalizowany, a praktyka taka jest stosowana na szeroką skalę za granicą; wystarczy ograniczyć się tu do podanych wcześniej przykładów wieży Eiffla w Paryżu czy zamku Tower w Londynie. Nie ma przeto przeszkód, aby zacząć stosować ją także

41 Kopia, hasło w: Mała encyklopedia PWN. 


\section{ARTYKUŁY}

Wojciech Kowalski

w Polsce, ale skuteczne wykorzystanie wyglądu zabytków w marketingu miast musi jednak uwzględniać istniejące $w$ naszym kraju uwarunkowania prawne w tym zakresie, które stwarzają skądinąd na tym polu spore możliwości.

W pierwszej kolejności należy podkreślić ich bezpośrednie źródło, a mianowicie prawo własności, które w myśl art. 140 k.c. upoważnia właściciela do korzystania z zabytku na zasadzie wyłączności, a nadto do pobierania z niego pożytków i innych dochodów. Obejmuje ono zatem nie tylko oczywiste dla wszystkich prawo korzystania z jego materialnego komponentu poprzez użytkowanie własne lub wynajem powierzchni, ale także mniej powszechnie dostrzegane prawo korzystania z jego wyglądu i udostępniania go innym osobom. To ostatnie prawo dotyczy przy tym nie tylko możliwości oglądania budynku w sensie dosłownym, tzn. patrzenia na zabytek in situ, ale również dysponowania jego wyglądem, który utrwalony został na fotografii lub innym nośniku. Jeżeli chodzi o pierwszą sytuację, to jest ona znana z codziennej praktyki sprzedawania biletów za wstęp do obiektów zabytkowych i muzeów, która jest powszechnie przyjęta, a same bilety stanowią w istocie rzeczy opłatę za możliwość zapoznania się zwiedzających z wyglądem obiektu i jego wyposażenia. Na tej samej zasadzie odbywa się udostępnianie wyglądu za „pośrednictwem” fotografii, filmu lub innego nośnika obrazu. Trudno bowiem byłoby racjonalnie wyjaśnić inne ewentualnie traktowanie korzystania z wyglądu poprzez bezpośrednie oglądanie, a inne korzystania z tego samego wyglądu, tyle że „oderwanego” od obiektu dzięki rejestracji na nośniku. Na podstawie tych argumentów brak, zdaniem autora, przeszkód, aby za pożytki i dochody z rzeczy w rozumieniu powołanego wyżej art. 140 k.c. uznawać zarówno dochody z bezpośredniego korzystania z wyglądu, jak i z korzystania z niego za pośrednictwem utrwalenia fotograficznego, filmowego itp. Prawo ich pobierania jest przy tym czymś innym niż prawa autora tej fotografii bądź filmu, które wynikają ze stworzenia tych utworów i oceniane są w świetle prawa autorskiego. Wnioski w tej części podsumowania należy jeszcze uzupełnić o uwagę, że podkreślona wyłączność właściciela w korzystaniu z jego zabytku nie ogranicza praw osób trzecich do oglądania obiektów znajdujących się w wolnym dla wszystkich dostępie, a także wykonywania przez te osoby fotografii dla użytku osobistego, tzn. w celu innym niż komercyjny.

Opisywane zagadnienie było przedmiotem różniących się orzeczeń za granicą, a także przedmiotem dyskusji z głosami zarówno krytycznymi, jak i aprobującymi. W Polsce wypowiedziało się na ten temat tylko kilku przedstawicieli doktryny, przy czym jeden z nich zajął stanowisko krytyczne. Sąd negatywnie ocenił natomiast zakaz fotografowania bez zgody i opłaty ustanowiony w regulaminie jednego z muzeów, ale w istocie nie było to stanowisko odnoszące się do omawianego zagadnienia, gdyż orzeczenie zapadło na tle sprawy zupełnie innego rodzaju. Przedmiotem oceny sądu był bowiem wspomniany punkt regulaminu jedynie pod kątem ewentualnego uznania go za niedozwoloną klauzulę umowną. Wprawdzie na skutek braku odwołania wyrok ten się utrzymał i może sprawiać wrażenie, że prawo pobierania 
Miasta i ich symbole. Uwarunkowania prawne marketingowego wykorzystywania...

Cities and their symbols. Legal conditions for marketing use...

opłat za fotografowanie w muzeum nie przysługuje, ale uznawany jest on jednak za błędny. Nie może przeto stanowić podstawy stwierdzenia braku możliwości prawnej określania przez muzea w ich regulaminach sposobu i zakresu korzystania z wyglądu obiektów wystawionych w nich do oglądania, włącznie z prawem do wprowadzenia nawet całkowitego zakazu fotografowania. Pogląd ten został zaaprobowany w naszej doktrynie prawnej.

Ustalając istnienie opisanego prawa wyłącznego wynikającego z własności zabytku, należy jednocześnie dodać, że sytuacja prawna ulegnie modyfikacji, kiedy zabytek ten poddany zostanie koniecznym przekształceniom w wyniku prac konserwatorskich, restauratorskich, adaptacyjnych, modernizacyjnych lub jest rekonstrukcją. Natura wymienionych prac jest w istocie różna, czym innym jest zwykle konserwacja i restauracja, a czym innym adaptacja i modernizacja, ale prawna ocena tych prac w kontekście zabytku jest co do zasady podobna. We wszystkich tych przypadkach projekty takich prac są najczęściej utworami w rozumieniu art. 1 prawa autorskiego, a zatem ich twórcy, czyli konserwatorzy czy architekci, są autorami, których prawa są tą ustawą chronione. Aby ustalić przedmiot tej ochrony w praktyce, to znaczy wkład tych osób do całości zabytku istotny w kontekście omawianego zagadnienia, trzeba będzie oddzielić wygląd części dawnej od wyglądu części nowej, która została wprowadzona w wyniku wymienionych wyżej prac i stanowi utwór chroniony na rzecz jego twórcy lub twórców. W zakresie tej drugiej części wyglądu zabytku prawom przysługującym jego właścicielowi towarzyszyć będą równoległe prawa autorskie konserwatora lub architekta. Będą to przy tym nie tylko prawa majątkowe determinujące warunki rozpowszechnianie ich utworu, ale także autorskie prawa osobiste z art. 16 prawa autorskiego, m.in. polegające na możliwości żądania oznaczania tego utworu swoim nazwiskiem lub pseudonimem albo do udostępniania go anonimowo.

Zasadniczo inaczej niż w przypadku skutków prawnych omówionych prac kształtuje się sytuacja rekonstruktora, który nie jest twórcą utworu zawartego w wykonywanej przez niego rekonstrukcji, lecz jedynie technicznym wykonawcą jego ponownego utrwalenia, dokonanego „zgodnie z zasadami konserwacji”. Nie przysługują mu zatem prawa autorskie do tej rekonstrukcji, aczkolwiek samo autorstwo jego pracy jako jej wykonawcy podlega ochronie opisanej w art. 23 i 24 k.c. Ochronie prawnoautorskiej podlegać będą mogły jedynie dodane przez rekonstruktora fragmenty, których kształt nie był np. znany z dostępnej dokumentacji i musiały być wobec tego stworzone na podstawie jego wiedzy i talentu.

W sposób podobny przedstawia się kwalifikacja prawna pracy kopisty, czyli wiernego odtworzenia wszystkich elementów kopiowanego dzieła. Przy rekonstrukcji odtworzenie zabytku odbywa się jedynie na podstawie zachowanych o nim informacji, natomiast przy kopiowaniu wykonawca dysponuje oryginałem. W obu sytuacjach nie mamy jednak do czynienia z pracą twórczą, lecz jak wspomniano - ochronie podlega tylko autorstwo wykonania rekonstrukcji lub kopii. 


\section{ARTYKUŁY}

Wojciech Kowalski

Podsumowującym wnioskiem końcowym powyższych rozważań jest w opinii autora istnienie po stronie właściciela wyłącznego prawa korzystania, w tym również dysponowania wyglądem budowli zabytkowych. W szczególności obejmuje ono korzystanie z tego wyglądu w celach komercyjnych, czy to poprzez bezpośrednie oglądanie, czy też za pośrednictwem fotografii i innych nośników służących do utrwalania owego wyglądu. Jeżeli zatem w marketingu miasta ma być wykorzystany wygląd zabytków stanowiących własność danej gminy miejskiej, to wykonując to prawo, może ona w pełni korzystać z ich wyglądu w swoim marketingu. Gdyby zaś były one własnością innego podmiotu, to niezbędne będzie zawarcie z nim odpowiedniej umowy. Korzystając natomiast z wyglądu zabytku, który uwidacznia wyniki wykonanych prac konserwatorskich, restauratorskich lub adaptacyjnych i modernizacyjnych, miasto będzie musiało uwzględnić prawa autorskie twórców projektów tych prac, $w$ tym prawa majątkowe związane z rozpowszechnianiem ich utworów, oraz ujawnić ich autorstwo w sposób z nimi ustalony. Gdyby zaś zabytek był rekonstrukcją lub kopią, wówczas obowiązek ten dotyczy tylko autorstwa ich wykonawcy.

\section{Bibliografia}

Barta J., Markiewicz R., Problemy prawa autorskiego związane z rewaloryzacją zabytkowych budowli, „Kwartalnik Prawa Prywatnego” 1993, t. 3.

Dąbrowski J., Problem rekonstrukcji części gotyckiej zamku oraz przywrócenia zespołu wnętrz z czasów Władysława IV, „Ochrona Zabytków” 1949, nr 2-4.

Dreier T., Restoration as a work protected by copyright?, w: Q. Byrne-Sutton, M.M. Renold, B. Rötheli-Mariotti (red.), La restauration des objets d'art. Aspects juridiques et étiques. The Restoration of Works of Art. Legal and Ethical Aspects, Etudes en droit de l'art, vol. 6, Schulthess, Zürich 1995.

Drela M., Własność zabytków, C.H. Beck, Warszawa 2006.

Forder C., Who's Afraid of Red, Yellow and Blue III?, „International Journal of Cultural Property" 1994, vol. 3, nr 2.

Ignatowicz J., Stefaniak K., Prawo rzeczowe, wyd. 3, LexisNexis, Warszawa 2009.

Korpal G., Artystyczny aspekt procesu konserwacji, w: B. Szmygin (red.), Współczesne problemy teorii konserwacji w Polsce, Międzynarodowa Rada Ochrony Zabytków ICOMOS, Politechnika Lubelska, Warszawa-Lublin, 2008.

Korpal G., Wokół kreacji, w: E. Szmit-Naud, B.J. Rouba, J. Arszyńska (red.), Wokół zagadnień estetyki zabytku po konserwacji i restauracji, Narodowy Instytut Dziedzictwa, Warszawa-Toruń 2012.

Kowalski W., A Comparative Law Analysis of the Retained Rights of Artists, „Vanderbilt Journal of Transnational Law" 2005, vol. 38, nr 4.

Kowalski W., Conservation of Works of Art under Polish Copyright Law, „Art, Antiquity and Law" 1999, vol. 4, nr 2. 
Miasta i ich symbole. Uwarunkowania prawne marketingowego wykorzystywania...

Cities and their symbols. Legal conditions for marketing use...

Kowalski W., Inteligentne miasta, a ich własność intelektualna. Status prawny oraz ochrona i używanie nazw i herbów, w: I. Jonek-Kowalska, J. Kaźmierczak (red.), Inteligentny rozwój inteligentnych miast, CeDeWu, Warszawa 2020.

Kowalski W., Ograniczenia prawne zmiany estetyki zabytku w trakcie jego konserwacji i restauracji, w: E. Szmit-Naud, B.J. Rouba, J. Arszyńska (red.), Wokół zagadnień estetyki zabytku po konserwacji i restauracji, Narodowy Instytut Dziedzictwa, Warszawa-Toruń 2012.

Kowalski W., Pojęcie i zakres własności intelektualnej muzeów, w: P. Stec, P.P. Maniurka (red.), Kolekcje muzealne i zbiory. Problematyka prawna, Redakcja Wydawnictw Wydziału Teologicznego Uniwersytetu Opolskiego, Opole 2015.

Kowalski W., Prawna problematyka konserwacji zabytków, w: B. Szmygin (red.), Współczesne problemy teorii konserwatorskiej w Polsce, Międzynarodowa Rada Ochrony Zabytków ICOMOS, Politechnika Lubelska, Warszawa-Lublin, 2008.

Kowalski W., Prawno-autorska ochrona architektury XX wieku, „Ochrona Dziedzictwa Kulturowego" 2017, vol. 3.

Kowalski W., Wartość zabytku a wartość adaptacji i modernizacji w świetle prawa autorskiego oraz prawa dziedzictwa kulturowego. Wzmocnienie ochrony czy konkurencja tych wartości?, w: B. Szmygin (red.), Ochrona wartości w procesie adaptacji zabytków, Polski Komitet Narodowy ICOMOS, Muzeum Pałacu Króla Jana III w Wilanowie, Politechnika Lubelska, Warszawa 2015.

Kowalski W., Zalasińska K., Prawo do wyglądu muzealiów i ich fotografowania, „Państwo i Prawo" 2013, z. 2.

Mała encyklopedia PWN, PWN, Warszawa 1992.

Masik G., Studzińska D., Ewolucja koncepcji i badania miasta inteligentnego, „Przegląd Geograficzny" 2018, 90(4).

Niewęgłowski A., Poźniak-Niedzielska M., Przyborowska-Klimczak A., Ochrona niematerialnego dziedzictwa kulturowego, Wolters Kluwer, Warszawa 2015.

Traple E., Komentarz do art. 33, w: J. Barta, M. Czajkowska-Dą̧browska, Z. Ćwiąkalski, R. Markiewicz, E. Traple, Prawo autorskie i prawa pokrewne, Wolters Kluwer, Warszawa 2011.

Ustawa z dnia 23 kwietnia 1964 r. Kodeks cywilny, tekst jedn. Dz. U. z 2020 r., poz. 1740, 2320, z 2021 r., poz. 1590.

Ustawa z dnia 23 lipca 2003 r. o ochronie o ochronie zabytków i opiece nad zabytkami, Dz. U. Nr 162, poz. 1568, ze zm. zm.

Ustawa z dnia 4 lutego 1994 o prawie autorskim i prawach pokrewnych, Dz. U. Nr 24, poz. 83 ze zm. zm.

Wojciechowski K., Ochrona obrazu rzeczy, „Przegląd Prawa Handlowego” 2005, nr 1.

Zachwatowicz J., Zagadnienie odbudowy zamku jako rekonstrukcji jego formy i wnętrza. Zamek Warszawski. „Ochrona Zabytków” 1949, nr 2-4.

Zbierska E., Żuraw Gdański, Wydawnictwo Gdańskie, Gdańsk 1993.

\section{Orzeczenia sądowe}

BGH, U. v. 20.09.1974, Az. IZR 99/73.

Cour de Cassation, Assemblée plènière, du 7 mai 2004, 02-10.450 Bulletin 2004 A. P. No 10, 21. 


\section{ARTYKUŁY}

Wojciech Kowalski

Cour de Cassation, Chambre civile 1, du 10 mars 1999, 96-18.699, Bulletin 1999 I No 87, 58. OLG Köln, U. v. 25.02.2003, 15 U 138/02.

Trib. Civ. 1re, du 2 mai 2001, JCP 2000. II. 10553.

Wyrok Naczelnego Sądu Administracyjnego w Warszawie z dnia 5 grudnia 2013 r., sygn. akt I FSK 1750/12, niepubl.

Wyrok Sądu Ochrony Konkurencji i Konsumentów z dnia 5 marca 2010 r., sygn. akt XVII Amc 1145/09, „Monitor Sądowy i Gospodarczy” 2010, 147, 9641. 